\title{
Growth rates constrained by internal and external imbalances and the role of relative prices: Empirical evidence from Portugal.
}

\begin{abstract}
Thirlwall's Law (Thirlwall 1979) considers that growth can be constrained by the balance-of-payments when the current account is in permanent deficit. The Law focuses on external imbalances as impediments to growth and does not consider the case where internal imbalances (budget deficits or public debt) can also constrain growth. The recent European public debt crisis shows that when internal imbalances are out of control they can constrain growth and domestic demand in a severe way. Recently, Soukiazis E., Cerqueira P., and Antunes M. (2012) developed a model - hereafter the SCA model - that takes into account both internal and external imbalances but where relative prices do not play any role on the pace of economic growth. The aim of this paper is to extend the SCA model by relaxing this assumption and introduce explicitly relative prices in it. The model is tested for Portugal which recently (2011) fell into a public debt crisis with serious negative consequences on growth. It is shown that our new model makes a significant improvement in explaining actual growth in Portugal. Our empirical analysis reveals that Portuguese growth is balance-of-payments constrained and that policies aiming at reducing external imbalances and changing the share of imports and exports towards trade equilibrium will help the economy to grow faster. Competitive devaluations and lower cost for financing the economy are also important stimulus to growth.
\end{abstract}

JEL code: $\mathrm{C} 32, \mathrm{E} 12, \mathrm{H} 6, \mathrm{O} 4$

Keywords: internal and external imbalances, price and income elasticities of external trade, equilibrium growth rates, 3SLS system regressions. 


\section{Introduction}

Thirlwall (1979) developed a simple model that determines the long run rate of growth of an economy consistent with the balance-of-payments equilibrium. According to this rule, actual growth can be predicted by the ratio of export growth to the income elasticity of demand for imports ${ }^{1}$. Thirlwall (1982) showed that his Law is equivalent to the dynamic form of the Harrod's foreign trade multiplier. There are two main controversial assumptions on the model: balance-of-payments equilibrium (on current account) and relative prices or real exchange rates remain constant in the long term analysis. According to what became known as Thirlwall's Law, no country can grow faster than its balance of payments equilibrium growth rate, unless it can continuously finance external deficits by capital inflows. Growth is constrained by external demand, and balance-of-payments disequilibrium on the current account can be a serious obstacle to higher growth when it cannot be financed by available foreign resources. Another crucial implication of the model is that it is income and not relative prices that adjust to bring the economy back to equilibrium.

Later on, Thirlwall and Hussain (1982) revised the model relaxing the assumption that the balance-of-payments is initially in equilibrium. Since countries can run current account deficits, capital inflows can be included in the model to determine the long term growth rate. This model has shown to be more realistic especially for developing countries where external imbalances can be sustained by capital inflows that alleviate the pressure on external payments. A large number of empirical studies emerged testing

\footnotetext{
1 Thirlwall's Law is given by $\dot{y}=\frac{\dot{x}}{\pi}$ where $\dot{y}$ is the growth of domestic income, $\dot{x}$ is the growth of real exports, and $\pi$ is the income elasticity of the demand for imports. To obtain this simple form relative prices are assumed to be constant and balance of payments is in equilibrium (on the current account). For an application of this Law to Portugal see Soukiazis E. and M. Antunes (2012).
} 
the validity of Thirlwall's Law or criticising the basic assumptions that it relies on. Among others, McCombie (1989), Moreno-Brid (1998-99), McCombie and Thirlwall (1994) and recently Blecker (2009) have made valuable contributions discussing and criticising the underlying implications of the Law.

The hypothesis of constant relative prices has been criticized widely in empirical literature (e.g. McGregor and Swales, 1985; 1991; Alonso and Garcimartín, 1998-99; López and Cruz, 2000). But in most studies in this field, relative prices have been shown to be statistically insignificant and even when they are significant the price elasticities with respect to imports and exports are very low in magnitude when compared to the income elasticities, showing that imports and exports are less sensitive to price changes than to income changes. Alonso and Garcimartín (1998-99) showed that the assumption that prices do not matter in determining the equilibrium income is neither a necessary nor a sufficient condition to assert that growth is constrained by the balance-of-payments. The empirical evidence seems to support the idea that income is the variable that adjusts to equilibrate external imbalances, implying therefore that growth is indeed balance-of-payments constrained. Blecker (2009) also stressed that it is safe to conclude that the longer the time period considered, the more likely is that relative prices remain constant. On the other hand, increasing capital inflows can at most be a temporary way of relaxing the balance-of-payments constraint, since they do not allow a country to grow at the export-led cumulative growth rate in the long-term. What matters in the long-term analysis of growth is the growth of exports.

Although Thirlwall's model has been modified to include capital flows and foreign debt, these studies have not considered the role of public imbalances as an additional constraint on growth. The external imbalance considered so far in the literature includes external debt (see for instance Barbosa-Filho, 2002) but the impact of public imbalances 
on overall growth has not been analysed separately. The recent experience of some peripheral European countries falling into a public debt crisis is the motivation to deal with this issue. As Pelagidis and Desli (2004) argue, the implementation of an expansionary fiscal policy, aiming at strengthening growth rates and reducing unemployment, would not always achieve the desirable objectives. It could be the case that budget deficits, financed either by money printing or by public borrowing, would increase public debt and interest rates, crowd out private investments, fuel inflation, and damage medium-term growth. The issue of whether budget deficits are always desirable has many dimensions, including whether government borrowing is financing government consumption or investment in infrastructure, whether the deficit is sustainable, and how it is financed. On the other hand, the hesitation of many policy makers - especially in Europe - to rely more aggressively on fiscal policy measures in order to keep their public finances more or less balanced may lead to the possibility of a vicious cycle between low growth and higher deficit formation as a result of the reduction of tax revenues.

Our paper aims at contributing to this debate by developing an alternative growth model, in line with Thirlwall's Law, that takes into account not only external, but also internal imbalances due to budget deficits and public debt. The model also considers that relative prices can play a significant role in the pace of economic growth. The reduced form of the growth of domestic income is determined, among other things, by factors related to fiscal policy and public finances that could affect economic growth negatively. The theoretical model is tested for the Portuguese economy that has recently been facing a serious problem with financing its public debt and thus called for external intervention in 2011. The implemented restrictive measures are expected to have negative repercussions on growth in the following years. Taking all these facts into 
account, the paper is organized as follows: in section 2 we develop the theoretical growth model controlling for internal and external imbalances and relative price movements; section 3 tests the model for the Portuguese economy trying to identify the main determinants of growth; a scenario analysis is provided in section 4 focusing on the factors that could foster growth in Portugal, and the last section concludes.

\section{Growth model with internal and external imbalances and the role of relative} prices.

Recently, Soukiazis et al. (2012) developed a multi equation model - henceforth the SCA model - to derive the reduced form of income growth which depends, among other things, on internal and external imbalances. However, for the sake of simplification the model assumed that relative prices do not play a significant role on economic growth and that in the long-term international relative prices remain constant. In this paper we relax this controversial assumption. The model is in line with the balance of payments constrained growth hypothesis with three particular differences: (i) it considers not only external imbalances (current account deficits), but also internal imbalances emerging from public deficit and debt; (ii) it considers the import contents of the components of demand; (iii) relative prices are introduced into the growth model and this is the main difference from our previous SCA model.

\subsection{Import Demand Function}

We start developing the model by specifying the demand for imports equation. Contrary to the conventional specification that considers real domestic income as the main aggregate determinant of the demand for imports, we use the components of domestic income to explain import flows. Alternatively to the SCA model, we assume that relative prices do play a significant role and that in the long run they can affect 
economic growth ${ }^{2}$. According to these assumptions, the import demand equation is specified as follows ${ }^{3}$ :

$$
M=\alpha C^{\pi_{c}} G^{\pi_{g}} X^{\pi_{x}} \operatorname{Inv} v^{\pi_{k}}\left(\frac{P^{*} e}{P}\right)^{\delta_{m}}
$$

where $M$ is imports, $C$ private consumption, $G$ government expenditures, $X$ exports and Inv investment, all expressed at constant prices. In addition, $P$ and $P^{*}$ are domestic and foreign price levels, respectively and $e$ the prevailing exchange rate (the price of foreign currency in terms of domestic currency units) $)^{4}$. In this equation, $\pi$ represents the elasticity of imports with respect to each of the components of demand. These elasticities are all expected to be positive since all components of demand have import content. In addition, $\delta_{m}<0$ is the relative price elasticity of demand for imports with an expected negative sign.Taking logs and differentiating through time we can define the same equation in growth rates, where a lower-case letter with a dot denotes the instantaneous growth rate of a given variable:

$$
\dot{m}=\pi_{c} \dot{c}+\pi_{g} \dot{g}+\pi_{x} \dot{x}+\pi_{k} i \dot{n} v+\delta_{m}\left(\dot{p}^{*}+\dot{e}-\dot{p}\right)
$$

In this way, the growth in demand for imports $\dot{m}$ depends on the growth rates of private consumption $\dot{c}$, government expenditures $\dot{g}$, exports $\dot{x}$, and investment $i \dot{n} v$, respectively. Additionally, the growth of imports depends on the growth of domestic $\dot{p}$

\footnotetext{
${ }^{2}$ The hypothesis that relative prices remain constant in the long term is a debatable assumption made in some studies for the sake of simplifying the specification of the model. As we explained before, there are studies showing that relative prices are important in international trade and explain a substantial part of growth especially in developing countries. Concerning Portugal, Garcimartín et al. (2010-11) attribute the slowdown of economic growth in Portugal to the overvaluation of the domestic currency (loss of price competitiveness) when the country joined the Euro zone.

${ }^{3}$ The time index $t$ is not attached to the variables for the sake of simplification.

${ }^{4}$ When $e$ increases shows a currency depreciation of domestic currency.
} 
and foreign $\dot{p}^{*}$ prices respectively, and the variation of the exchange rate $\dot{e}$ over time.

The next step is to determine the growth rates of the components of demand.

\subsection{Export Demand Function}

In this function it is assumed that foreign income $Y^{*}$ and relative prices of exports $\left(\frac{P^{*} e}{P}\right)$ are the main determinants of export demand. It is explicitly assumed that exports competitiveness is based on price and non-price competitiveness captured by the price and income elasticity of the demand for exports, respectively. Therefore, we assume that relative prices change in the long-term analysis, contrary to the one price hypothesis assumed in our previous SCA model. Having this in mind, the export equation is defined as:

$$
X=\beta Y^{* \varepsilon_{x}}\left(\frac{P * e}{P}\right)^{\delta_{x}}
$$

where $\varepsilon_{x}>0$ is the income elasticity of demand for exports capturing the non-price characteristics of the exported goods associated with quality, design, reliability, varieties, etc ${ }^{5}$. Additionally, $\delta_{x}>0$ is the relative price elasticity of export demand with an expected positive sign. Expressing this equation in growth rates we get:

$$
\dot{x}=\varepsilon_{x} \dot{y}^{*}+\delta_{x}\left(\dot{p}^{*}+\dot{e}-\dot{p}\right)
$$

\footnotetext{
${ }^{5}$ Although we assume that the income elasticity of demand for exports captures the quality characteristics of the produced goods we do not neglect the fact that changes in relative prices can be related to changes in relative quality as well.
} 
where $\dot{x}$ is the growth of real exports, $\dot{y}^{*}$ the growth of real foreign income, $\dot{p}$ and $\dot{p}^{*}$ the growth of domestic and foreign prices respectively, and $\dot{e}$ the exchange rate variation.

\subsection{Private final consumption}

The final consumption of households is a function of total disposable income and the yields obtained by holding government bonds:

$$
C=\left[\left((1-t)+r w_{B H}\right) Y\right]^{\varepsilon_{c}}
$$

where $t$ is the tax rate on income, $r$ is the real interest rate ${ }^{6}, w_{B H}$ is the share of home bond holders on public debt, and $\varepsilon_{c}$ is the income elasticity of consumption. Taking growth rates the consumption equation becomes:

$$
\dot{c}=\varepsilon_{c}\left(\frac{(\Delta r) w_{B H}+r\left(\Delta w_{B H}\right)}{(1-t)+r w_{B H}}+\dot{y}\right)
$$

Assuming that the share of home bond holders on public debt does not change over time, $\Delta w_{B H}=0$, the consumption function reduces to:

$$
\dot{c}=\varepsilon_{c}\left(\frac{(\Delta r) w_{B H}}{(1-t)+r w_{B H}}+\dot{y}\right)
$$

or alternatively

$$
\dot{c}=\varepsilon_{c}\left(\dot{y}+\frac{(\Delta i-\Delta \dot{p}) w_{B H}}{(1-t)+r w_{B H}}\right)
$$

\footnotetext{
${ }^{6}$ Real interest rate is the difference between nominal interest rate $i$ and domestic inflation, $r=i-\dot{p}$.
} 
since $\Delta r=\Delta(i-\dot{p})=\Delta i-\Delta \dot{p}$

Therefore, consumption growth is a function of the growth of domestic income and interest rate revenues obtained by holding government bonds. In the estimation we will assume that consumption growth is a function of disposable income growth.

\subsection{Private Investment}

The private investment function is derived from the flexible accelerator model, first suggested by Goodwin (1951) and Chenery (1952), where gross investment (denoted by

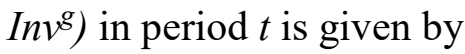

$$
\operatorname{In} v_{t}^{g}=\lambda\left(K_{t}^{d}-K_{t-1}\right)+\delta K_{t-1}
$$

In this equation $K^{d}$ is the desired amount of capital stock, $K$ is the effective capital stock in the economy, $\lambda$ is the speed of adjustment and $\delta$ the depreciation rate.

The desired capital stock is assumed to be a function of domestic income $(Y)$ and the real interest rate $(r)$, defined as

$$
K_{t}^{d}=Y_{t}^{\varepsilon_{K d}} r_{t}^{\varepsilon_{r d}}
$$

where $\varepsilon_{K d}$ and $\varepsilon_{r d}$ are the elasticities of desired capital stock with respect to income and real interest rate. Replacing equation (10) in (9) and taking variations at $t$, we get $^{7}$

$$
\begin{aligned}
& \Delta \operatorname{In} v_{t}^{g}=\Delta\left(\lambda K_{t}^{d}\right)=\Delta\left(\lambda Y_{t}^{\varepsilon_{K d}} r_{t}^{\varepsilon_{r d}}\right)= \\
& =\frac{\lambda Y_{t}^{\varepsilon_{K d}-1} r_{t}^{\varepsilon_{r d}}}{Y_{t}^{\varepsilon_{K d}-1}} \varepsilon_{K d} \frac{\Delta Y_{t}}{Y_{t}} Y_{t}^{\varepsilon_{K d}}+\frac{\lambda Y_{t}^{\varepsilon_{K d}} r_{t}^{\varepsilon_{r d}-1}}{r_{t}^{\varepsilon_{r d}-1}} \varepsilon_{r d} \frac{\Delta r_{t}}{r_{t}} r_{t}^{\varepsilon_{r d}}
\end{aligned}
$$

${ }^{7}$ Since $K_{t-l}$ is given at period t. 
Since $\frac{\Delta Y_{t}}{Y_{t}}=\dot{y}$ and $\frac{\Delta r_{t}}{r_{t}}=\dot{r}$ are growth rates, we have

$$
\Delta \operatorname{In} v_{t}^{g}=\lambda r_{t}^{\varepsilon_{r d}} Y_{t}^{\varepsilon_{K d}} \varepsilon_{K d} \dot{y}+\lambda r_{t}^{\varepsilon_{r d}} Y_{t}^{\varepsilon_{K d}} \varepsilon_{r d} \dot{r}
$$

Dividing (12) by $\operatorname{In} v_{t}^{g}$ and rearranging terms we obtain

$$
\frac{\Delta \operatorname{In} v_{t}^{g}}{\operatorname{In} v_{t}^{g}}=\lambda \frac{K_{t}^{d}}{\operatorname{In} v_{t}^{g}}\left(\varepsilon_{K d} \dot{y}+\varepsilon_{r d} \dot{r}\right)
$$

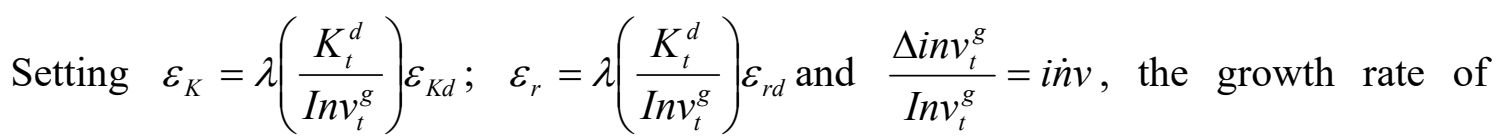
investment is given by

$$
i \dot{n} v=\varepsilon_{K} \dot{y}+\varepsilon_{r} \dot{r}
$$

Therefore, investment growth is a function of the growth rates in domestic income and real interest rates. It is expected that $\varepsilon_{k}>0$ (the accelerator effect) and $\varepsilon_{r}<0$ reflecting the impact of real cost in financing investment.

\subsection{Government sector}

We consider that the government budget is given by the following identity, in nominal terms:

$G_{n}+i B_{H}+i * B_{F} e=t Y P+D$

where $G_{n}$ is nominal government expenditures, $B_{H}$ is public debt ${ }^{8}$ owned by home bond holders, $B_{F}$ is public debt owned by foreign bond holders, $Y$ is domestic income, $P$ is the domestic price level, $D$ the public deficit, $i$ and $i^{*}$ are nominal interest rates paid to home and foreign public debt holders, respectively, $e$ the nominal exchange rate, and $t$ is

\footnotetext{
${ }^{8}$ Public debt is originated by issuing government bonds to finance public deficit.
} 
the tax rate on nominal income. According to this relation, public deficit exists when total current expenditures (including interest payments on public debt) exceed the revenues obtained through taxes on domestic money income, i.e, $G_{n}+i B_{H}+i * B_{F} e>t Y P$.

As it is shown in Soukiazis et al. (2012a) (see Appendix A, Equation A.5), the long term relationship of the growth of real government expenditures $\dot{g}$ is given by:

$$
\dot{g}=\frac{t \dot{y}}{w_{G}}+(\dot{d}-\dot{p}) \frac{w_{D}}{w_{G}}-\left[\Delta i+i\left(\dot{b}_{H}-\dot{p}\right)\right] \frac{w_{B H}}{w_{G}}-\left[\left(e \Delta i^{*}+i^{*} \Delta e\right)+i^{*} e\left(\dot{b}_{F}-\dot{p}\right)\right] \frac{w_{B F}}{w_{G}}
$$

where $w_{D}=\frac{D}{Y P}$ is the budget deficit ratio, $w_{G}=\frac{G}{Y}$ is the government spending ratio, $w_{B H}=\frac{B_{H}}{P Y}$ and $w_{B F}=\frac{B_{F}}{P Y}$ are the shares of public debt owned by home and foreign bond holders (as a percentage of nominal income), respectively, $\dot{d}$ is the growth of budget deficit and $\dot{b}_{H}$ and $\dot{b}_{F}$ are the growth rates of the public debt owned by home and foreign bond holders, respectively.

\subsection{Balance-of-payments condition}

The last relation of the model is an external equilibrium condition given by the following identity:

$$
X P+D_{F} e-i * B_{F} e=M P^{*} e
$$

The left hand side of the identity shows the money resources available to finance imports (export revenues plus the amount of public deficit assets hold by foreigners minus interest rate payments on foreign bond holders). 
It is shown in Soukiazis et al. (2012a) (see Appendix B, Equation (B.6)) that the balance of payments final relation can be expressed as:

$$
\dot{x}+\dot{p}+(1-\xi) \frac{w_{D}}{w_{X}}\left(\dot{p}+\dot{y}-i^{*}\right)-(1-\xi) \frac{w_{B}}{w_{X}} \Delta i^{*}=\frac{w_{M}}{w_{X}} \frac{P^{*} e}{P}\left(\dot{m}+\dot{p}^{*}+\dot{e}\right)
$$

where $\dot{x}, \dot{m}, \dot{p}, \dot{p}^{*}, \dot{y}$ and $\dot{e}$ are growth rates of exports, imports, domestic prices, foreign prices, domestic income and nominal exchange rate, respectively. Additionally, $w_{D}, w_{B}, w_{M}$ and $w_{X}$ are the ratios of budget deficit, public debt, imports and exports on income, respectively. Finally $(1-\xi)$ represents the percentage of public deficit (or debt) which is financed by external markets.

\subsection{Domestic income growth}

Following a similar procedure as in Soukiazis et al. (2012a) (see Appendix C, Equation (C.4)) the growth rate of domestic income is given by the following relation:

$$
\dot{y}=\frac{A}{B}
$$

where

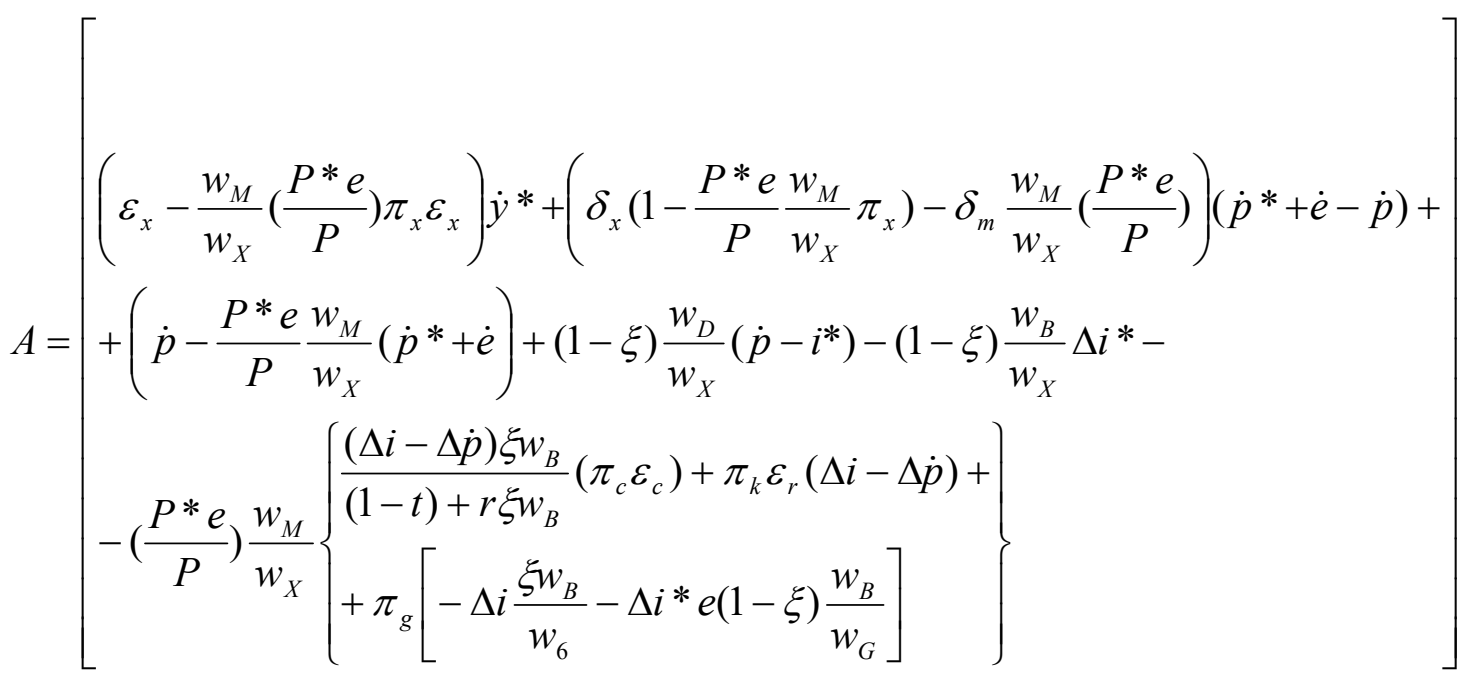




$$
\begin{aligned}
& B=\frac{w_{M}}{w_{X}}\left(\frac{P^{*} e}{P}\right)\left\{\pi_{c} \varepsilon_{c}+\pi_{k} \varepsilon_{k}+\pi_{g}\left(\frac{t}{w_{G}}+\frac{w_{D}}{w_{G}}-\frac{i \xi w_{B}}{w_{G}}-i * e(1-\xi) \frac{w_{B}}{w_{G}}\right)\right\}- \\
& -(1-\xi) \frac{w_{D}}{w_{X}}
\end{aligned}
$$

Equation (19) shows that, among other factors, the growth of domestic income is determined by internal and external imbalances, taking also into account the effect of relative prices. In particular the nominator $A$ is decomposed in various terms: the first term measures the impact of foreign demand on domestic growth, the second term reflects the substitution effect through the movements of relative prices, the third term is the volume effect of trade, and the rest measures the impact of internal imbalances on domestic growth. The denominator captures basically the effect of the disaggregated import elasticities of the components of demand on domestic growth. Equation (19) will be used to predict actual growth in Portugal.

\section{Testing the model for the Portuguese economy}

The import demand equation (2), the export demand equation (4), the private consumption equation (8) and the investment equation (14) are estimated simultaneously to obtain the elasticities which are needed to compute the reduced form of domestic income growth as it is expressed by equation (19). Annual data are used covering the period 1986-2010, thus starting at the year that Portugal joined the early EEC. The definition of the variables and the data sources are explained in Appendix A. The method used for estimating the system equations is 3SLS (Three-Stage Least Squares) as it is more efficient to capture the interrelation between equations and the causal and feedback effects between the core variables of the system. Table B.1 in the Appendix B provides the estimation results where simultaneity is controlled by using instrumental variables. The growth of imports, consumption, investment, and exports 
are assumed to be endogenous as well as the growth of government expenditures, domestic disposable income, domestic product, real exchange rate and real domestic interest rate. All other variables in the system are assumed exogenous, including some lagged variables, as it is explained in Table B.2.

In general the estimation results are quite satisfactory; all elasticities carry their expected signs and are statistically significant with few exceptions. The relative price elasticity is statistically significant in the import equation (at the 5\% level) and carries the correct negative sign but in the export demand equation caries a wrong negative $\operatorname{sign}^{9}$. The value of the relative price elasticities is low in comparison with the income elasticities, confirming the general finding in the literature that trade is more sensitive to income than to price changes. The striking fact in the import demand function is the high elasticity of consumption, which exceeds unity $\left(\pi_{c}=1.349\right)$ indicating that imports increase more than proportionally with respect to consumption increase. Although the elasticity of imports with respect to exports and investment are also relevant, thus indicating a significant import content in these elements of demand, they are lower ( $\pi_{x}=0.317$ and $\pi_{k}=0.359$ respectively). An unexpected result is the negative elasticity of imports with respect to government spending $\left(\pi_{g}=-0.378\right)$ and statistically significant at the $1 \%$ level. This could signify an import substitution policy of the government spending giving preference to the domestic goods and services.

Table B.1 also shows that investment and exports are income elastic with respect to domestic and foreign income, respectively $\left(\varepsilon_{k}=2.17\right.$ and $\left.\varepsilon_{x}=2.88\right)$, the former confirming the accelerator principle in the investment function, and the latter showing

\footnotetext{
${ }^{9} \mathrm{An}$ increase in relative prices reflects devaluation and a decrease a valuation of domestic currency. The same wrong sign of the relative prices on exports also found in previous studies for Portugal see for instance, Soukiazis E. and Micaela Antunes (2012) and Bairam (1988).
} 
the high sensitivity of exports relative to external demand (the OECD income growth). This high export dependence on foreign income should be a case of concern in periods of economic slowdown in foreign markets. Consumption is income inelastic, as expected $\left(\varepsilon_{c}=0.818\right)$ but with a sizeable value. Finally, the impact of real interest rate on investment is negative $\left(\varepsilon_{r}=-1.178\right)$, an expected result since this variable measures the real cost of financing investment projects.

We also regressed each of the equations individually, by $2 S L S$ (see Table B.2 in Appendix B) using the same instruments. The intention was to carry out some diagnostic tests to justify the robustness of our results. The first is the Sargan statistic, a test of over-identifying restrictions to check the validity of the instruments used in the regressions and that hypothesis is confirmed in all cases. The second is the Pagan-Hall heteroskedasticity test, showing that the hypothesis of homoskedasticity is never rejected. The third test is the Cumby-Huizinga test for autocorrelation. The null hypothesis is that errors are not first-order autocorrelated and this is confirmed in all cases.

Table I below reports the values which are necessary for computing the growth rates of domestic income in Portugal. Some are estimated values taken from Table B.1 (Appendix B) others are annual averages over the period considered (see Appendix A for variable definition and data sources). Three growth rates are computed: $\dot{y}_{a}$ obtained from equation (19) where internal and external imbalances are considered and relative prices are not neutral; $\dot{y}_{b}$ determined by the SCA model with relative prices being constant, and $\dot{y}_{c}$ obtained from Thirlwall's original Law, given by $\dot{y}=\frac{\dot{x}}{\pi}$. In the latter case, it was necessary to estimate the import demand function 
$\dot{m}=\pi \dot{y}+\delta_{m}\left(\dot{p}^{*}+\dot{e}-\dot{p}\right)$ by OLS (with robust standard errors) to obtain the aggregate import elasticity with respect to income growth $(\pi=2.633)$.

Comparing these different growth rates with the actual average growth in Portugal over the period 1986-2010 ( $\dot{y}=2.728 \%$ ) the following remarks can be made:

(i) The growth rate obtained by Thirlwall's original Law $\left(\dot{y}_{c}=2.338 \%\right)$ using the aggregate income elasticity of imports $(\pi=2.633)$ is quite close to the actual growth rate $(\dot{y}=2.728 \%)$ in Portugal making therefore, an accurate prediction. According to the interpretation of the Law, the Portuguese economy grew, on average, 0.39 percentage points (per annum) above the rate allowed by the balance-of-payments equilibrium. We have to recall that Thirlwall's Law is a restrictive form in the sense that it assumes that balance of payments is in equilibrium, relative prices are not

Table I. Computation of the growth rates of domestic income. Portugal, 1986-2010

\begin{tabular}{|c|c|c|c|c|c|c|c|c|}
\hline $\begin{array}{l}\varepsilon_{x} \\
2.877\end{array}$ & $\begin{array}{l}\pi_{x} \\
0.317\end{array}$ & $\begin{array}{l}\varepsilon_{6} \\
0.818\end{array}$ & $\begin{array}{l}\pi_{6} \\
1.349\end{array}$ & $\begin{array}{l}\varepsilon_{k} \\
2.170\end{array}$ & $\begin{array}{l}\pi_{k} \\
0.359\end{array}$ & $\begin{array}{l}\pi_{g} \\
-0.378\end{array}$ & $\begin{array}{l}\varepsilon_{x} \\
-1.178\end{array}$ & $\begin{array}{l}\hat{\delta}_{m} \\
-0.501\end{array}$ \\
\hline$\hat{\delta}_{x}$ & $t$ & $r$ & $\dot{p}$ & $\dot{y}^{*}$ & $w_{D}$ & $w_{G}$ & $w_{B}$ & $\bar{\xi}_{D}$ \\
\hline-0.463 & 0.360 & 0.027 & 0.057 & 0.025 & 0.050 & 0.378 & 0.588 & 0.401 \\
\hline $\bar{\xi}_{B}$ & $w_{M}$ & $w x$ & $i$ & $i^{*}$ & $\Delta i$ & $\Delta i^{*}$ & $e$ & $\dot{e}$ \\
\hline 0.401 & 0.364 & 0.280 & 0.084 & 0.055 & -0.009 & -0.002 & 0.972 & 0.013 \\
\hline$\left(\frac{p^{*} e}{p}\right)$ & $\dot{p}^{*}+\dot{e}-\dot{p}$ & $(\Delta-\Delta \dot{p})$ & $\dot{p}^{*}$ & $\left(\dot{p}-i^{*}\right)$ & & & & \\
\hline 1.087 & -0.012 & -0.001 & 0.026 & 0.002 & & & & \\
\hline$\dot{y}_{a}$ & $\dot{y}_{b}$ & $\dot{y}_{c}$ & $\dot{y}$ & & & & & \\
\hline 1.9946 & 1.640 & 2.338 & 2.728 & & & & & \\
\hline $\begin{array}{l}\text { Internal and } \\
\text { external } \\
\text { imbalances and } \\
\text { relative prices } \\
\text { nonueutral } \\
\text { Equation (19) }\end{array}$ & $\begin{array}{l}\text { Internal and } \\
\text { external } \\
\text { imbalances and } \\
\text { relative prices } \\
\text { neutral }\end{array}$ & $\begin{array}{l}\text { Thirlwall's } \\
\text { Law } \\
\dot{y}=\frac{\dot{x}}{\pi}\end{array}$ & $\begin{array}{l}\text { Actual } \\
\text { growth }\end{array}$ & & & & & \\
\hline
\end{tabular}

Notes: $\varepsilon_{x}, \pi_{x}, \varepsilon_{c}, \pi_{c}, \varepsilon_{k}, \pi_{k}, \pi_{g}, \varepsilon_{r}, \delta_{m}$ and $\delta_{x}$ are taken from Table B.1 (see Appendix B).

$r, t, w_{D}, w_{G}, w_{B}, w_{M}, w_{X}, i, i^{*}, e, \dot{p}$ and $\dot{y}^{*}$ are annual averages over the period 1986-2010. $\xi_{D}$ and $\xi_{B}=0.401$ is assumed constant over the whole period. 
playing any significant role on growth and no internal imbalances are considered in the model.

(ii) The growth rate obtained by our model which considers internal and external imbalances and relative prices are not neutral, given by equation (19) $\left(\dot{y}_{a}=1.9946 \%\right)$, under-predicts also actual growth in Portugal. The difference between the predicted by our model and actual growth is now higher ( 0.73 percentage points) than in the case of Thirlwall's Law. This result shows that Portugal should grow by a lower rate than actually did in order not to aggravate internal and external imbalances. In other words, Portugal grew faster than the rate allowed by the balance-of-payments equilibrium and its public financial capability at the cost of accumulating internal and external deficits and this can explain the recent debt crisis of the country. In order to grow faster without deteriorating internal and external imbalances some improvements have to be made on structural parameters and especially on those related with competitiveness. We will show that more explicitly in the scenario analysis of the next section.

(iii) The fact that Portugal grew at a higher average growth rate than that predicted by both, our model and Thirlwall's Law, can be explained by capital inflows financing this extra growth. The higher actual growth was obtained at the expense of accumulating higher external debt over time corresponding to 233\% of GDP in 2009. On the other hand, the lower growth rate predicted by our model is due to the fact that internal imbalances imply capital outflows via interest rate payments on debt. Therefore, they play a similar role as imports, restricting growth in the long-run.

(iv) Substantially different results are obtained when relative prices are considered in our model. Our previous model with no relative prices (the so called SCA model, 
Soukiazis et al. (2012)) predicted an even lower average growth rate, around $0.28 \%$, in comparison to approximately $2 \%$ rate found by the new model where relative price movements are controlled for. Therefore, the difference can be attributed to the contribution of relative prices mostly affecting the import and export sectors as we have concluded from the regression analysis (see Table B.1 in Appendix B).

An important explanation for the lower growth performance predicted by our model lies in the high import sensitivity of the components of demand, especially that of consumption $\left(\pi_{c}=1.349\right)$. This elasticity shows that if consumption increases by one percentage point (p.p.) this will induce a 1.349 p.p. increase in imports (more than proportionally). Therefore, a high amount of domestic consumption is spent on imported goods and could be responsible for the balance of payments deficits on the current account.

The high import sensitivity of the components of demand explains the high income elasticity of the demand for imports at the aggregate level $\pi=2.633$ showing that imports grow more than twice the increase in domestic income. The high penetration of imports can also be observed by the share of imports on income, around $w_{M}=36 \%$, with exports representing $w_{X}=28 \%$ only. Therefore the multiplier effects of the components of demand on growth are not substantial in the Portuguese economy as they are counterbalanced by the increase in imports.

We have to notice here that what is important in international trade is not importing too much in order to produce domestic and exportable goods, but ensuring that the transformation of imported components into domestic goods and exports contains enough value-added. In international markets, most produced goods and exports embody a substantial share of imported components, but in terms of gains it is important 
that the value (price) - especially of exports embodying imported components - is sufficiently higher than the value (price) of those imported components. Traditionally, Portugal produces (and exports) low value-added domestic goods (due to low productivity) despite the move from low to medium or medium-high technology exports in recent years $(\mathrm{OECD}, 2008)$. On the other hand, the share of the service sector in the overall economy has risen, representing $75.4 \%$ of the gross value added against $22.3 \%$ in industry and $2.3 \%$ in agriculture. However, labour productivity gains have been particularly weak and became negative since the beginning of the current decade. The service sector involves mainly a high number of micro enterprises (wholesale, retail, hotels and restaurants) with a substantial proportion of non-tradables and high informality (OECD Economic Survey, 2010).

\section{A scenario analysis}

Some simulations can be made with the aim at detecting the factors that could help the economy to grow faster.

(i) Fiscal policy towards a reduction in income taxation. If taxation on income reduces from $t=36 \%$ to $20 \%$ (everything else constant) the predicted growth by our model is $\dot{y}_{a}$ $=1.79 \%$ which is lower than that found in Table I $\left(\dot{y}_{a}=1.99 \%\right)$. It seems that a more friendly taxation policy alone is not efficient to stimulate higher growth.

(ii) Budget deficit policy aiming at reducing public deficit and debt ratio. If we assume $w_{D}=0.03$ and $w_{B}=0.60$ (the values imposed by the Growth and Stability Pact i.e., deficit of $3 \%$ and debt of $60 \%$ of the GDP) the predicted growth is around $\dot{y}_{a}=1.93 \%$ which is also lower than that found in Table I. Therefore public budget discipline alone does not help the economy to grow faster. 
(iii) Interest rate policy. A monetary policy attempting to reduce domestic interest rates from $8.4 \%$ (the prevailing average rate for the whole period) to $5 \%$ (implying $\Delta i=-$ 0.034 ) or $3 \%$ (implying $\Delta i=-0,054)$, induces a slightly higher growth (than that of Table I), equivalent to $\dot{y}_{a}=2.42 \%$ and $\dot{y}_{a}=2.76 \%$, respectively. On the other hand, if foreign interest rates $^{10}$ rise from $i^{*}=5.5 \%$ (the prevailing average for the whole period) to $i^{*}=7 \%$ (the rate that forced Portugal to ask for the "troika" intervention in 2011) and $\Delta i^{*}=0.015$, the predicted growth falls from $\dot{y}_{a}=1.99 \%$ to $\dot{y}_{a}=0.55 \%$ which is a drastic drop. It is therefore shown that growth in Portugal is more sensitive to changes in external foreign interest rate, due to increase in interest rate payments to serving external debt. A scenario to equalize domestic and foreign interest rates to a lower rate equal to $i=i^{*}=4 \%$ (implying $\Delta i=-0.044$ and $\Delta i^{*}=-0.015$ ) predicts a higher domestic growth of $\dot{y}_{a}=3.75 \%$. Therefore, financing domestic economy with lower interest rates is a big stimulus to growth. This is an interesting result favouring the recent argument on issuing Eurobonds, which will allow member countries to finance their economies at a lower cost.

(iv) The novelty in this new model (in comparison to our initial SCA model) is that now we assume that relative prices are not neutral. If we assume that relative prices are constant in the long-run, that is, $\dot{p}^{*}+\dot{e}-\dot{p}=0$ and therefore $\left(\mathrm{P}^{*} \mathrm{e} / \mathrm{P}\right)=1, \mathrm{e}=1$ and $\dot{e}=0$ which also implies that $\dot{p}=\dot{p}^{*}=0.02644$ (the average foreign inflation rate), and replace these values into our model (equation (19)) the obtained growth rate is $\dot{y}_{a}$ $=2.13 \%$. Assuming the same conditions but setting the foreign inflation equal to domestic inflation rate $\dot{p}=\dot{p}^{*}=0.05668$, the obtained domestic growth rate becomes $\dot{y}_{a}=1.64 \%$. In both cases the result is different from the one found when relative

\footnotetext{
${ }^{10}$ In this study we use long term interest rates of the German economy as the benchmark for foreign interest rates.
} 
prices are not neutral $\dot{y}_{a}=1.99 \%$ (see Table I). Therefore relative prices make a considerable difference in the growth pace and when they are ignored the model can miss-predict actual growth rate in Portugal.

(v) Another scenario is to assume $\dot{p}^{*}+\dot{e}-\dot{p}=0,\left(\mathrm{P}^{*} \mathrm{e} / \mathrm{P}\right)=1, \mathrm{e}=1$ (nominal exchange rate is fixed) and therefore $\dot{e}=\dot{p}-p^{*}=0.03024$. In this case real exchange rate is determined by the difference between domestic and foreign inflation rate which is 3 percentage points higher in Portugal. Implementing this scenario in our model the predicted domestic growth is $\dot{y}_{a}=1.64 \%$ which is lower from that found in Table I. The lower growth rate is explained by the loss of price competitiveness of the Portuguese economy due to a higher inflation differential with regards to foreign market competitors. Another conclusion we can derive from this scenario is that Portugal could obtain higher economic growth rates with flexible exchange rates due to competitive devaluation that manages to equalize domestic and foreign prices.

(vi) In consequence of the above argument it is interesting to check a scenario where there is a change in the average value of the growth of real relative prices (or real exchange rate) for the whole period from $\dot{p}^{*}+\dot{e}-\dot{p}=-0.012$ to 0.02 or 0.03 representing a depreciation of domestic currency. In this case it is shown that growth increases to $\dot{y}_{a}=2.7 \%$ or $2.93 \%$, respectively, confirming the hypothesis that a currency devaluation ${ }^{11}$ is a stimulus to growth increasing the country's competiveness in foreign markets.

(vii) Reducing the import sensitivity of exports (elasticity) from $\pi_{x}=0.31$ (see Table I) to 0.20 our model predicts a higher growth rate equal to $\dot{y}_{a}=2.62 \%$. It is

\footnotetext{
${ }^{11}$ However, this is not an option for Portugal since the country belongs to the euro zone and nominal exchange rates are fixed. Even if devaluation was an option this should be continuous to have permanent growth effects.
} 
therefore shown that lowering the import sensitivity of exports alone, is a stimulus to growth. When the import content of exports is high the exports' multiplier effects on income are crowded out by higher imports. Reducing the import content of exports is an appropriate policy to achieving higher growth.

(viii) Reducing the share of imports by only 4 percentage points (from $36 \%$ to $32 \%$ ) the predicted growth is $\dot{y}_{a}=2.94 \%$; or alternatively increasing the share of exports by 4 percentage points (from $28 \%$ to $32 \%$ ) the obtained growth is also higher, $\dot{y}_{a}=2.93 \%$. A combined policy with the aim to equilibrate the import and export shares $w_{M}=w_{X}=0.30$ yields an even higher growth equal to $4.04 \%$. Therefore changing the structure of the shares of imports and exports towards an equilibrium level is the appropriate way to enhance higher growth.

(ix) Our model also shows that the Portuguese economic growth is highly dependent on foreign demand through the income elasticity of the demand of exports which is highly elastic ( $\varepsilon_{x}=2.877$ see Table I). Assuming a small drop in external demand (the average growth rate of the OECD countries) from $\dot{y}^{*}=2.5 \%$ to $2 \%$ our model predicts a drop in domestic growth from $\dot{y}_{a}=1.99 \%$ to $1.62 \%$. A higher drop in external demand $\dot{y}^{*}=1.5 \%$ will induce an even lower growth in Portugal $\dot{y}_{a}=1.24 \%$. Therefore, Portugal will face severe growth problems in case of an economic slowdown in international markets.

(x) Finally, an alternative scenario could be to determine the equilibrium growth rate of the Portuguese economy with no internal and external imbalances and neutral relative prices. For concreteness, the following conditions are assumed: export share equal to import share $w_{X}=w_{M}$, therefore $w_{M} / w_{X}=1$; constant relative prices $\dot{p}^{*}+\dot{e}-\dot{p}=0$ thus $\left(P^{*} e / P\right)=1, e=1$ and $\dot{e}=0$; and zero deficit and debt ratio $w_{D}=w_{B}=0$. Replacing 
these values in equation (19) the equilibrium growth rate is very high $\dot{y}_{a}=5.15 \%$. However, the above assumptions are not plausible and can over predict growth rates in Portugal.

According to these hypothetical scenarios it is clearly shown that the most effective policy to achieve higher growth in Portugal applies to the trade sector, towards a balanced external trade and changing the structure of imports and exports. This is in line with Thirlwall's Law asserting that growth can be balance-of-payments constrained when trade deficits are high ${ }^{12}$. Our evidence also shows that relative prices are relevant in the growth process and that competitive devaluation is a stimulus to growth in Portugal. Finally, financing the economic activity by lower interest rate costs is also beneficial to growth.

\section{Concluding remarks}

The aim of this study was to develop a more complete growth model in line with Thirlwall's Law that takes into account both internal and external imbalances and assuming that relative prices are not neutral. The important contribution of the extended model is that it distinguished the import content of aggregate demand and introduces public deficit and debt measures as determinants of growth. Additionally, the model controls for relative prices movements and this is the main difference from our previous model (the SCA model). The reduced form of the model shows that growth rates can be obtained in three alternative ways: assuming internal and external imbalances and no neutrality in relative prices; assuming internal and external imbalances but neutral relative prices; and lastly the growth rate predicted by Thirlwall's Law. The growth

\footnotetext{
12 The current account deficit in Portugal was always negative in this period of analysis with an average value of $-5.5 \%$ as a percentage of GDP (for more details see Soukiazis and Antunes, 2012).
} 
model is tested for the Portuguese economy over the period 1986-2010 to check its accuracy.

The equations constituting the model are estimated by $3 S L S$ to control the endogeneity of the core variables and to obtain consistent estimates. The empirical analysis shows that growth rates obtained by Thirlwall's Law accurately predict the average growth rate of the Portuguese economy over the period 1986-2010 although it is slightly lower than the actual growth. However, Thirlwall's Law considers some controversial assumptions, namely that external trade is balanced, public finances are at equilibrium, and relative prices are neutral. Testing our model where trade and public imbalances are allowed and relative prices are not neutral the predicted growth rate is slightly lower than that predicted by Thirlwall's Law (and the actual growth) and this is consistent mostly with the external trade disequilibria the country has been accumulating over the years. We believe that our model is a more complete one since it relaxes all the controversial assumptions of Thirlwall's Law and takes into account a variety of factors that could explain in a more explicit way the pace of growth.

The scenarios implemented to explain the lower growth rates (than actual growth) predicted by our model point to the fact that policies aiming at equilibrating external deficits or changing the structure of imports and exports are the most effective for achieving higher growth. Competitive devaluation also acts as a stimulus to growth. It is also shown that economic growth in Portugal is highly dependent on external demand. Policies designed to achieve better conditions of financing internal imbalances, and reducing the payment costs of public debt are beneficial to growth. To some extent, Portugal could benefit from the challenging idea of issuing Eurobonds to finance its public debt in the European market with lower costs. 
Appendix A : Description of the variables and data sources

- $\dot{m}_{t}-$ annual growth rate of real imports - Imports of goods and services at 2000 prices (national currency; annual percentage change).

- $\quad \dot{c}_{t}$ - annual growth rate of final private consumption - Private final consumption expenditure at 2000 prices (national currency; annual percentage change).

- $\dot{x}_{t}-$ annual growth rate of real exports - Exports of goods and services at 2000 prices (national currency; annual percentage change).

- $\quad \dot{k}_{t}-$ annual growth rate of investment - Gross fixed capital formation at 2000 prices (national currency; annual percentage change).

- $\quad \dot{y}_{t}$ - annual growth rate of real GDP - GDP at 2000 market prices (national currency; annual percentage change).

- $\quad \dot{p}_{t}-$ annual growth rate of price deflator GDP at market prices (national currency; annual percentage change).

- $\quad \dot{p}_{t}^{*}$ annual growth rate of price deflator GDP at market prices, for the EU-12 (national currency; annual percentage change).

- $w_{G}$ - share of government's expenditure on GDP - Total expenditure; general government minus interest including flows on swaps and FRAs (\% of GDP at market prices; excessive deficit procedure).

- $w_{D}$ - share of government's deficit on GDP - Net lending (-) or net borrowing $(+)$; general government ( $\%$ of GDP at market prices; excessive deficit procedure).

- $w_{B}$ - share of government's debt on GDP - General government consolidated gross debt $(\%$ of GDP at market prices; excessive deficit procedure).

- $w_{M}$ - imports of goods and services at current prices (national accounts) - $\%$ of GDP at market prices

- $w_{X^{-}}$. exports of goods and services at current prices (national accounts) - \% of GDP at market prices.

- $t$ - share of government's revenues on GDP - Total current revenue; general government (\% of GDP at market prices; excessive deficit procedure).

- $i$ - nominal long-term interest rates $(\%)$

- $i^{*}$ - nominal long-term interest rates (\%) for Germany

Data on $\dot{m}_{t}, \dot{c}_{t}, \dot{x}_{t}, \dot{k}_{t}, \dot{y}_{t}, \dot{p}_{t}, \dot{p}_{t}^{*}, w_{G}, w_{D}, w_{B}, w_{M}, w_{X}, t, i$ and $i^{*}$ were taken from European Commission (2011). 
- $\quad \dot{g}_{t}-$ annual growth rate of government's expenditure. Computed by the authors from data on "General government expenditure by function (Millions of euro from 1.1.1999/ECU up to 31.12.1998)" (for 1990 on) and "General government expenditure (Millions of euro from 1.1.1999/ECU up to 31.12.1998)" (till 1989), from Eurostat http://epp.eurostat.ec.europa.eu/portal/page/portal/statistics/themes (extracted on $29^{\text {th }}$ February 2012 and $14^{\text {th }}$ January 2011, respectively) and information on $\dot{p}_{t}$.

- $\dot{y}^{*}$ - annual growth rate of real foreign income (OECD countries). Computed by the authors using information about "Gross domestic product, GDP per head, US \$, constant prices, constant PPPs, reference year 2005”, from OECD.StatExtracts - http://stats.oecd.org/ (extracted on $15^{\text {th }}$ December 2011)

- $\quad \dot{y}_{d}-$ annual growth rate of real disposable income. Computed by the authors using information about "Net national disposable income (national currency, constant prices, national base year)", from OECD.StatExtracts - http://stats.oecd.org/ (extracted on $10^{\text {th }}$ March 2012)

- $e$-nominal effective exchange rate - price of domestic currency in terms of foreign currency - index $(2010=100)$ narrow indices (27 countries). Computed by the authors using monthly data, from the Bank for International Settlements(BIS)- http://www.bis.org/statistics/eer/index.htm (extracted on $18^{\text {th }}$ May 2012)

- $\left(P^{*} e / P\right)$ - real effective exchange rate index $(2010=100)$, narrow indices (27 countries). Computed by the authors using monthly data, from the Bank for International Settlements(BIS)http://www.bis.org/statistics/eer/index.htm (extracted on $18^{\text {th }}$ May 2012) 
Appendix B

Table B.1. The 3SLS estimation of the structural growth model: Portugal 1986-2010.

\begin{tabular}{|c|c|c|c|c|c|c|c|}
\hline & Coefficient & Std Error & t-stat & p-value & $\mathbf{R}^{2}$ & F-stat & p-value \\
\hline \multicolumn{8}{|c|}{ Imports growth } \\
\hline constant & 2.229 & 0.900 & 2.48 & $0.015^{* *}$ & \multirow{6}{*}{0.9211} & \multirow{6}{*}{53.54} & \multirow{6}{*}{0.000} \\
\hline & 1.349 & 0.351 & 3.85 & $0.000 * * *$ & & & \\
\hline & -0.378 & 0.122 & -3.10 & $0.003 * * *$ & & & \\
\hline & 0.317 & 0.075 & 4.23 & $0.000 * * *$ & & & \\
\hline & 0.359 & 0.120 & 3.00 & $0.004 * * *$ & & & \\
\hline$\left.t^{*}+\dot{e}_{t}-\dot{p}_{t}\right)$ & -0.501 & 0.233 & -2.15 & $0.034^{* *}$ & & & \\
\hline \multicolumn{8}{|c|}{ Consumption growth } \\
\hline constant & 1.336 & 0.376 & 3.55 & $0.001 * * *$ & \multirow{2}{*}{0.6735} & \multirow{2}{*}{60.28} & \multirow{2}{*}{0.000} \\
\hline$\dot{y}_{\mathrm{d}, \mathrm{r}}$ & 0.818 & 0.105 & 7.76 & $0.000 * * *$ & & & \\
\hline \multicolumn{8}{|c|}{ Investment growth } \\
\hline constant & -3.302 & 0.918 & -3.6 & $0.001 * * *$ & \multirow{3}{*}{0.7845} & \multirow{3}{*}{41.83} & \multirow{3}{*}{0.000} \\
\hline$\dot{y}$, & 2.170 & 0.266 & 8.17 & $0.000 * * *$ & & & \\
\hline$r^{*} t$ & -1.178 & 0.402 & -2.93 & $0.004^{* * *}$ & & & \\
\hline \multicolumn{8}{|c|}{ Exports growth } \\
\hline constant & -1.683 & 1.261 & -1.33 & 0.186 & \multirow{3}{*}{0.6615} & \multirow{3}{*}{27.38} & \multirow{3}{*}{0.000} \\
\hline$\dot{y}_{t}^{*}$ & 2.877 & 0.397 & 7.26 & $0.000^{* * *}$ & & & \\
\hline$\left(\dot{p}_{t}^{*}+\dot{e}_{t}-\dot{p}_{t}\right)$ & -0.463 & 0.226 & -2.05 & $0.044^{* *}$ & & & \\
\hline
\end{tabular}


Table B.2. The 2SLS estimation of each equation of the structural model, 1986-2010.

\begin{tabular}{|c|c|c|c|c|c|c|c|}
\hline & Coefficient & Std Error & t-stat & p-value & $\begin{array}{c}\text { Sargan } \\
\text { test }\end{array}$ & $\begin{array}{c}\text { Heteroscedasticity } \\
\text { test }\end{array}$ & $\mathrm{AR}(\mathrm{l})$ test \\
\hline \multicolumn{8}{|l|}{ Imports growth } \\
\hline constant & 2.139 & 1.048 & 2.04 & $0.057^{*}$ & $\chi_{16}^{2}=21.88$ & $\chi_{21}^{2}=15.13$ & $\chi_{1}^{2}=0.61$ \\
\hline$\dot{c}_{t}$ & 1.351 & 0.408 & 3.31 & $0.004^{* *}$ & $p$-value $=0.1470$ & $p$-value $=0.8163$ & p-value $=0.4366$ \\
\hline$\dot{g}_{t}$ & -0.372 & 0.142 & -2.62 & $0.018^{* *}$ & & & \\
\hline$\dot{x}_{t}$ & 0.327 & 0.087 & 3.74 & $0.002^{* * *}$ & & & \\
\hline$\dot{k}_{t}$ & 0.355 & 0.139 & 2.55 & $0.021^{* *}$ & & & \\
\hline$\left(\dot{p}_{t}^{*}+\dot{e}_{t}-\dot{p}_{t}\right)$ & -0.489 & 0.271 & -1.8 & $0.089 *$ & & & \\
\hline \multicolumn{8}{|c|}{ Consumption growth } \\
\hline constant & 1.379 & 0.404 & 3.41 & $0.003 * * *$ & $\chi_{20}^{2}=19.49$ & $\chi_{21}^{2}=18.99$ & $X^{2}{ }_{1}=0.21$ \\
\hline$\dot{y}_{d, t}$ & 0.798 & 0.118 & 6.74 & $0.000 * * *$ & p-value $=0.4896$ & p-value $=0.5855$ & $p$-value $=0.6475$ \\
\hline \multicolumn{8}{|l|}{ Investment growth } \\
\hline constant & -3.176 & 0.987 & -3.22 & $0.004 * * *$ & $X_{19}^{2}=22.95$ & $\chi_{21}^{2}=16.23$ & $X^{2}{ }_{1}=0.15$ \\
\hline$\dot{y}$. & 2.117 & 0.286 & 7.39 & $0.000 * * *$ & p-value $=0.2396$ & p-value $=0.7567$ & p-value $=0.6996$ \\
\hline$r^{*} t$ & -1.315 & 0.436 & -3.02 & $0.007 * * *$ & & & \\
\hline \multicolumn{8}{|l|}{ Exports growth } \\
\hline constant & -1.55 & 1.428 & -1.09 & 0.291 & $X^{2} 19=22.93$ & $\chi_{21}^{2}=18.97$ & $\chi_{1}^{2}=0.39$ \\
\hline$\dot{y}_{t}^{*}$ & 2.871 & 0.468 & 6.14 & $0.000 * * *$ & $\mathrm{p}$-value $=0.240$ & p-value $=0.5872$ & $p$-value $=0.5338$ \\
\hline$\left(\dot{p}_{t}^{*}+\dot{e}_{t}-\dot{p}_{t}\right)$ & -0.378 & 0.274 & -1.38 & 0.184 & & & \\
\hline
\end{tabular}

Notes: Endogenous variables: $\dot{m}_{t}, \dot{c}_{t}, \dot{k}_{t}, \dot{x}_{t}, \dot{g}_{t}, \dot{r}_{t}, \dot{y}_{d}, \dot{y}_{t},\left(\dot{p}_{t}^{*}+\dot{e}_{t}-\dot{p}_{t}\right)$

Exogenous variables: $\dot{y}_{t}^{*}, t_{t}, w_{B, t}, w_{d, t}, w_{g, t}, i_{t}, \dot{p}_{t}, \dot{p}_{t}{ }^{*}, i_{t}^{*}, w_{D, t-1}, w_{G, t-1}, w_{B, t-1}, \dot{c}_{t-1}, \dot{x}_{t-1}, \dot{k}_{t-1}, \dot{g}_{t-1}, \dot{c}_{t-2}, \dot{x}_{t-2}, \dot{k}_{t-2}, \dot{g}_{t-2}, \dot{r}_{t-2}$ $*, * *, * * *$ Coefficient significant at the $10 \%, 5 \%$ and $1 \%$ level, respectively. 


\section{References}

Alonso, J., and C., Garcimartín. "A new approach to balance-of-payments constraint: some empirical evidence." Journal of Post Keynesian Economics. Winter 1998-99: 21(2), 259-282.

Bairam, E. "Balance-of-payments, the Harrod foreign trade multiplier and economic growth: the European and North American experience, 1970-1985." Applied Economics, 1988, 20, 1635-1642.

Barbosa-Filho, N. "The balance-of-payments constraint: from balanced trade to sustainable debt.” CEPA Working Paper. January, 2002:06.

Blecker, R. "Long-run growth in open economies: export-led cumulative causation or a balance-of-payments constraint?." Paper presented at the $2^{\text {nd }}$ Summer School on Keynesian Macroeconomics and European Economic Policies. 2 $2^{\text {nd }}-9^{\text {th }}$ August 2009: Berlin, Germany.

Chenery H. B. "Overcapacity and the Acceleration Principle." Econometrica, 1952:20, $1-28$.

European Commission. "Statistical Annex of European Economy." Directorate General Economic and Financial Affairs, Spring 2011.

Garcimartín, C., Rivas, L., and P. Martínez. "On the role of relative prices and capital flows in balance-of-payments constrained growth: the experiences of Portugal and Spain in the Euro Area." Journal of Post-Keynesian Economics. Winter 2010-11: 33 (2), 281-306.

Goodwin R.M. "The Non-linear Accelerator and the Persistence of Business Cycles." Econometrica, 1951:19(1), 1-17.

López J. and A. Cruz. "Thirlwall's Law and Beyond: the Latin American Experience." Journal of Post Keynesian Economics, 2000: 22(3), 477-495.

McCombie, J. "Thirlwall's Law" and balance-of-payments constrained growth - a comment on the debate." Applied Economics. 1989: 21, 611-629.

McCombie, J., and A. Thirlwall. "Economic growth and the balance-of-payments constraint.” MacMillan Press, Basingstoke; St. Martin's Press, 1994: New York.

McGregor, P., and J. Swales. "Professor Thirlwall and the balance-of-payments constrained growth." Applied Economics. 1985: 17, 17-32.

McGregor, P., and J., Swales. "Thirlwall's Law and balance-of-payments constrained growth: further comment on the debate." Applied Economics. 1991: 23, 9-23. 
Moreno-Brid, J. "On capital flows and the balance-of-payments-constrained growth model." Journal of Post Keynesian Economics. Winter, 1998-99: 21(2), 283-298.

Organization for Economic Co-operation and Development - OECD - Science, Technology and Industry Outlook, 2008.

Organization for Economic Co-operation and Development - OECD- Economic Survey, 2010.

Pelagidis, T., and E. Desli. "Deficits, growth, and the current slowdown: what role for fiscal policy?" Journal of Post Keynesian Economics, 2004: 26(3), 457-465.

Soukiazis, E., and M., Antunes. "Application of the balance-of-payments constrained growth model to Portugal, 1965-2008." Journal of Post Keynesian Economics. Winter 2012: 34(2), 41-66.

Soukiazis E., Cerqueira, P., and M., Antunes. "Modelling economic growth with internal and external imbalances: empirical evidence from Portugal." Economic Modelling, 2012: 29(2), 478-86.

Soukiazis E., Cerqueira, P., and M., Antunes. "Growth rates constrained by internal and external imbalances and the role of relative prices: empirical evidence from Portugal" Working Paper no8, GEMF, 2012a, http://gemf.fe.uc.pt

Thirlwall, A. "The balance-of-payments constraint as an explanation of international growth rate differences." Banca Nazionale del Lavoro, 1979: 128, 45-53.

Thirlwall, A. "The Harrod trade multiplier and the importance of export-led growth." Pakistan Journal of Applied Economics. 1982: 1(1), 1-21.

Thirlwall, A., and N., Hussain. "The balance-of-payments constraint, capital flows and growth rate differences between developing countries." Oxford Economic Papers. 1982: 34, 498-510. 